line. She was readmitted for drainage, and when the infection had subsided the flap was debrided and resutured. The abdominal wound healed well without infection.

Bacteriological findings-Direct examination of the haematoma fluid showed numerous polymorphs with intracellular and extracellular Gram negative bacilli $(2 \times 0.5 \mu \mathrm{m})$. The fluid and a swab from the wound yielded a pure growth of a non-lactose fermenting, oxidase positive, aerobic Gram negative bacillus, which was identified by the API system (appareil procédés d'identification) as Aeromonas hydrophila. As this organism is known to be harboured by leeches, ${ }^{5}$ two from the batch used to treat the patient were examined bacteriologically. After they had crawled over plates of blood agar and CLED agar they were killed, cut up, and inoculated on to various media, which were then incubated aerobically and anaerobically. The water in which the leeches had been transported was similarly cultured. A hydrophila was isolated from the three sets of cultures; in addition a strain of Providencia spp was isolated from the transport water. The isolates of $A$ hydrophila had the same pattern of antimicrobial sensitivity as that reported by Millership et $a l^{6}$ - that is, they were sensitive to sulphonamide, tetracycline, chloramphenicol, gentamicin, tobramycin, and both cefuroxime and cefotaxime. They were resistant to ampicillin, trimethoprim, erythromycin, and cephradine.

\section{Comment}

Leeches commonly harbour $A$ hydrophila. Whitlock et al drew attention to the possible risk of infection with this organism as a result of using leeches in microsurgery but did not themselves report any such infections. ${ }^{3}$ The wound infection described here was almost certainly acquired from the leeches used to decongest the flap in the reconstruction of the patient's breast. Although not common, infection due to $A$ hydrophila has been reported to have been acquired from various sources including fresh water, ${ }^{7}$ and clearly it cannot be disregarded as a human pathogen. Our report confirms that the leech is a potential source of wound infection.

We thank Mr M H C Webster for allowing us to report this case and Professor Morag C Timbury for helpful advice.

\section{References}

I Derganc M, Zdravid F. Venous congestion of flaps treated by application of leeches. Br Y Plast. Surg 1960;13:187-92

2 Henderson HP, Matti B, Laing AG, Morelli S, Sully I. Avulsion of the scalp treated by microvascular repair. The use of leeches for post-operative congestion. $\mathrm{Br} \mathcal{J}$ Plast Surg

3 Whitlock MR, O'Hare PM, Sanders R, Morrow NC. The medicinal leech and its use in plastic surgery: a possible cause of infection. Br 7 Plost Surg 1983:36:240-4

(a) flap. Plast Reconstr. Surg 1982:69:216-24.

5 Jennings JB, Van der Lande VM. Histochemical and bacteriological studies on digestion in nine species of leeches (annelida: hirudinea). Biol Bull 1967;33:166-71.

Millership SE, Curnow SR, Chattopadhyay B. Faecal carriage rate of Aeromonas hydrophila J Clin Pathol 1983;36:920-3.

McCracken AW, Barkley R. Isolation of aeromonas species from clinical sources. $\mathcal{I}$ Clin Pathol 1972;25:970-5

\title{
Lipoid pneumonia: an occupational hazard of fire eaters
}

\author{
BJÖRN BEERMANN， TONY CHRISTENSSON， PETER MÖLLER， ANNE STILLSTRÖM
}

Liquid paraffins are used as purgatives or nasal drops, and for lighting charcoal for barbecues: a low oral toxicity and a high flame point make them suitable for both purposes. Aspiration of paraffins into the lungs, however, may have deleterious effects. ${ }^{1-3}$ We report a severe case of pneumonia caused by inhalation of liquid paraffins in a fire eating woman.

\section{Case report}

A 29 year old female clown was admitted after inhaling a mouthful of an ignition fluid containing $20 \%$ isoparaffins and $80 \% \mathrm{n}$-paraffins. The accident had occurred while she was training to be a fire eater. The normal procedure is to blow out the fluid against a burning stick. Because of the high flame point only fluid in the form of an aerosol around the stick will burn, and there is small risk of the fire spreading to the mouth.

The patient suffered from cough, dyspnoea, and left sided severe chest pains aggravated on inspiration. There were no abnormal signs on examination except a cough and dullness at the left lung base on percussion. Chemical screening, including analysis of blood gases, showed no abnormality. Chest $x$ ray film showed a large homogeneous infiltrate in the basal part of the left lung (fig. 1). Treatment with corticosteroids and benzylpenicillin was

Department of Medicine, St Erik's Hospital, S-112 82 Stockholm, Sweden BJÖRN BEERMANN, MD, physician

TONY CHRISTENSSON, MD, physician

PETER MÖLLER, MD, physician

Department of Anaesthesiology, St Erik's Hospital, S-112 82 Stockholm, Sweden ANNE STILLSTRÖM, MD, physician

Correspondence to: Dr Björn Beermann. started. The chest pain was very intense and was relieved first after intercostal blockade and high doses of dextropropoxyphene and paracetamol.

The patient's condition deteriorated during the next week with fever up to $39 \cdot 4^{\circ} \mathrm{C}$. Analysis of blood gases showed a fall of oxygen pressure $\mathrm{PO}_{2}$ to $8 \cdot 4$ $\mathrm{kPa}(63 \mathrm{~mm} \mathrm{Hg})$, and the pulmonary infiltrates increased in size and pleural effusion appeared (fig 2). Erythrocyte sedimentation rate increased to 131

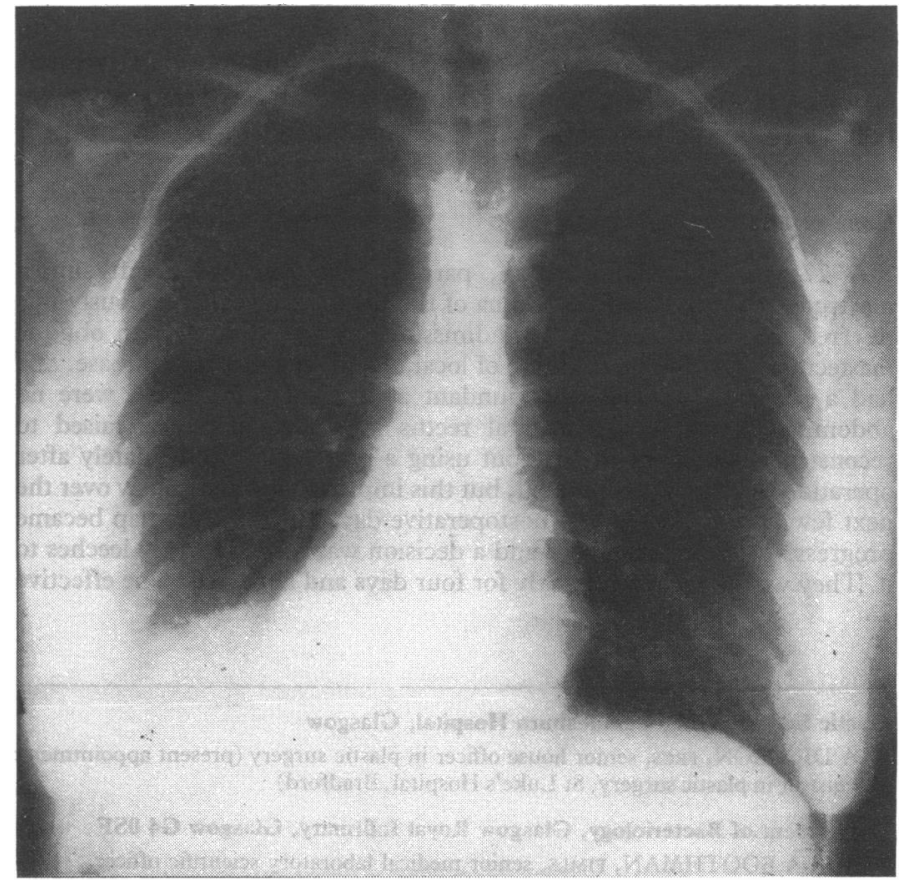

FIG 1 -Chest $x$ ray film immediately after inhalation of liquid paraffins. 


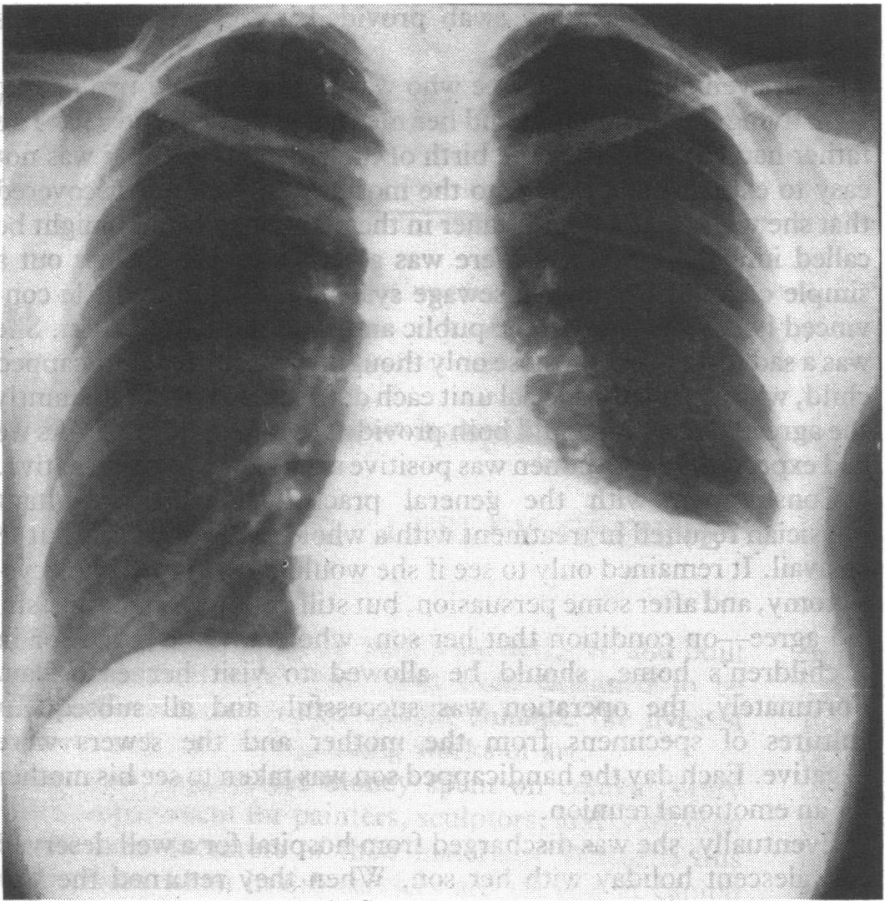

FIG 2 - Chest $x$ ray film one week after inhalation of liquid paraffins.

$\mathrm{mm}$ in the first hour and leucocytes to $22 \cdot 7 \times 10^{\%} / 1$ and haemoglobin concentration decreased to $10.3 \mathrm{~g} / \mathrm{dl}$.

Penicillin was changed to doxycycline and the corticosteroids were continued. Thereafter the condition of the patient improved. The fever abated slowly during the following two weeks, oxygen pressure returned to normal, and the chest $x$ ray film showed considerable improvement of the pulmonary abnormalities. After about three weeks in hospital the patient was well enough to be discharged. At check up about two months after the accident she had completely recovered. Chest $x$ ray film showed almost complete disappearance of the pulmonary abnormalities.

\section{Comment}

Inhalation or aspiration of paraffin produces two types of lesion: one is acute with pneumonia caused by massive administration into the lungs, and one is chronic with fibrosis and granulomatous reaction. ${ }^{1-3}$ The case described shows the acute form, which seems to be rare but easily diagnosed. The chronic type is seen in patients who use paraffins as purgatives or as nose drops. That reaction is caused by repeated aspiration or inhalation of small amounts of paraffin, is more difficult to diagnose, and should be remembered when a patient presents with unspecific nodular pulmonary changes on chest $x$ ray examination.

Paraffins are non-corrosive and are solvents of lipids, which most probably cause the damage to the lungs in the acute form. Our patient was treated with corticosteroids, though the efficacy of this treatment is disputed. ${ }^{45}$ Penicillin did not prevent the development of the abnormalities in the lung, with leucocytosis and high fever. As the aspirated material in cases like this is sterile it might be better not to give prophylactic antibiotic treatment routinely but only if signs of secondary infection appear.

\section{References}

Fox B. Liquid paraffin pneumonia-with chemical analysis and electronmicroscopy. Virchows Arch [Pathol Anat] 1979;382:339-46.

2 Olsen AM. The spectrum of aspiration pneumonitis. Ann Otol Rhinol Laryngol 1970;79:875-88.

Weill H, Ferrans VJ, Gay RM, Ziskind MM. Early lipoid pneumonia. Am $\mathcal{F}$ Med 1964;36:370-6.

${ }^{4}$ Marks MI, Chicoine L, Legeve G, Hillman E. Adrenocorticosteroid treatment of hydrocarbon pneumonia in children: a cooperative study . 7 Pediatr 1972;81:366-9.

5 Steele RW, Conklin RH, Mark HM. Corticosteroids and antibiotics for treatment of fulminant hydrocarbon aspiration. FAMA 1972;219:1434-7.

(Accepted 17 November 1983)

\title{
One small slip and its consequences
}

\author{
MALCOLM PLEYDELL
}

As a medical officer of health I used to find that just one or two cases of food poisoning, let alone an outbreak, were a cause for apprehension and concern. It was only in retrospect that I could regard them with the detached interest of a detective story.

But there was perhaps one exception to this generalisation. The incident began on a beautiful summer morning with two small boys who lived on a council estate on the outskirts of a borough with a population of about 60000 . The boys obtained their parents' consent to go fishing in a nearby stream, but once out of sight of the council houses they changed their minds and decided to explore the countryside. Soon they reached a fence with a "No Admission" sign. They promptly climbed through the wire and found themselves in a completely new world of large rectangular tanks separated by parapets. There was the fascinating sound of running

\section{Oxford OX2 9EY}

MALCOLM PLEYDELL, MD, DPH

Correspondence io: 31 Cumnor Hill, Oxford OX2 9EY. water; some of the tanks were full, some only partly filled; and there was a sweet but not unpleasant smell in the air. They had discovered the borough's sewage works.

They explored further, but in walking along the top of a parapet one boy lost his balance and fell into a settling tank. He regained his feet, and fortunately the water level only came up to his neck. The difficulty was that he could not reach the top of the parapet to pull himself out, and his friend looking anxiously down could not pull him out by his hands, his jersey, or his hair. It was one of those occasions when children suddenly become adults. In a hurried discussion the boys decided that the one who had fallen into the tank should stay exactly where he was, quite still, while his companion ran back to the housing estate to raise the alarm.

Not long afterwards the whole estate knew what had happened. Housewives in coloured aprons began running across the fields towards the sewage works, followed by men with ladders, ropes, and anything useful to hand. When they arrived they found that the boy was still safe where he had been left. He had not moved, and with the help of ladders and ropes he was pulled to safety. White with shock and exhaustion, he collapsed on the ground. Soon an ambulance arrived and he was taken away to the local infectious diseases hospital. Subsequent examinations showed that he had 